\title{
Research on Construction of Ecological Civilization System of Counties in China
}

\author{
Qian Li \\ Liaoning Party School of Central Committee of CPC \\ Shenyang, China 110004
}

\begin{abstract}
Industrial civilization has broken the balance between man and nature, and to improve the relationship between economic development and ecological environment, China is now vigorously promoting the construction of ecological civilization. Construction of ecological civilization in counties is the micro foundation, as well as an important link and key task of China's ecological civilization construction. Construction of ecological civilization is a long-term systemic project and will not be accomplished at one stroke, and the construction of ecological civilization system is the strong support and powerful guarantee of the project. From the perspective of system, the paper discusses the contemporary position of the construction of ecological civilization in counties of China as well as challenges it faces so as to find solution to the existing problems.
\end{abstract}

Keywords—county; ecological civilization; system

\section{INTRODUCTION}

From the perspective of historical dimension of civilization development, ecological civilization is the theoretical and practical achievement in sustainable development explored and established by human beings during their reflection on traditional industrial civilization under the background of nonsustainable resources, increasingly serious environment pollution and continuous ecological degradation caused by industrial civilization that breaks the balance between man and nature. The specific problems ecological civilization is expected to solve are resource, environmental and ecological problems so as to ensure sustainable development of the economic society and to resolve the conflicts and contradictions between man and nature since industrial civilization. The foundation and key to resolve the conflicts and contradictions for China lies in counties. As the micro foundation of construction of ecological civilization of China, construction of ecological civilization in counties is an important link and key task for China to construct ecological civilization, and its efficiency affects and even determines the realization of the overall effect. The development of ecological civilization is inseparable from functions of the system so it has to establish a systematic and complete system to construct ecological civilization, that is, using the system to protect the ecological environment. Ecological civilization system is the sum total of all kinds of guiding, normative and restrictive stipulations and norms that are formulated or formed in the whole society to support, promote and safeguard the construction of ecological civilization, including formal institutions in the level of laws, regulations and rules, together with the informal institutions in the level of ethics, morals and convention ${ }^{1}$.

\section{CuRRENT Positioning OF ECOLOGICAL CiVILIZATION CONSTRUCTION IN COUNTIES}

Firstly, ecological crisis is the self-exile of modern industrial civilization, the misplacement of the civilization and nature and the conflict between the maximization of desire and the limitation of resources. China has weak base of resources and energy, and the long-standing imbalance between supply and demand of energy continuously increases the resource pressure. In the meantime, environmental destruction has become the main reason that affects development quality and harms people's physical and mental health. According to 2016 Bulletin of China's Environmental Status, in 2016, land and resources departments carried out monitoring of groundwater quality in 6,124 monitoring points (including 1,000 nationallevel monitoring points) of 225 prefecture-level administrative regions of 31 provinces (districts, cities). The evaluation result shows that: monitoring points with water quality recognized as excellent, good, general, bad and worse account for $10.1 \%$, $25.4 \%, 4.4 \%, 45.4 \%$ and $14.7 \%$, respectively. In 2016, in 338 prefecture-level and above level cities of China, 84 of them reached the standard of urban ambient air quality, accounting for $24.9 \%$ of all cities; 254 of them were below the standard of urban ambient air quality, accounting for $75.1 \%$ of all cities. This shows that environmental problem in China is severe. To improve the improve the ambient air quality of cities, it is urgent to protect natural resources from the source through construction of ecological civilization system to restrict and regulate human behaviors in the process of utilizing resource and environment.

Secondly, ecological civilization is the "sublation" of agricultural civilization and industrial civilization, and requires the support from both the technical rationality and ecological rationality to achieve harmony between man and nature. Through reflection from the perspective of ecological civilization concept, current environmental problem in China is essentially the imbalance problem of economic structure caused by the development mode where the development is measured by the economic growth. Only when economic development is within the scope of the bearing capacity of resources and environment, can economic quality and profits be improved in essence. With the increasing improvement of living standards, more and more people call for ecological 
safety, thus gradually generating the ecological demand of "blue sky, green land and clean water". However, the large gap between the current environment quality and people's expectation, if not properly handled, will pose a threat to social stability. For example, in April 2015, people of Heyuan, Guangdong took to the street in protest at the construction of the thermal power plant. In addition, mass incidents of environment broke out successively in Lufeng of Guangdong, Nanchang, Beihai of Guangxi, Yangchun of Guangdong, Wuhan and other places to protest against construction (expansion) of substation, nuclear power plant, wharf, rehabilitation hospital, etc. NIMBY facilities.

Thirdly, China is comprehensively promoting the construction of ecological civilization and has achieved great development. On one hand, continuously improved laws and regulations provide guarantee for the construction of ecological civilization system in counties. The top-level design of public policy constantly takes the principles of "must not get temporary economic development at the expense of ecological environment", "achieve both economic benefit and ecological benefit" and "ecological benefit is economic benefit" as its value guidance. Since the 18th National Congress of the Communist Party of China, the government had released a series of environmental protection measures such as "the 10-Chapter Soil Pollution Action Plan", "the Tenmeasure Action Plan to Tackle Water Pollution" and "The Ten Measures to Prevent and Control Air Pollution"; made a comprehensive overhaul of the Environmental Protection Law of the People's Republic of China, Atmospheric Pollution Prevention and Control Law of the People's Republic of China and Wild Animal Conservation Law of the People's Republic of China; revised Marine Environment Protection Law of the People's Republic of China, Water Pollution Prevention and Control Law of the People's Republic of China, Law of the People's Republic of China on Environmental Impact Assessment and Law of the People's Republic of China on the Prevention and Control of Environment Pollution Caused by Solid Wastes; and formulated the Environmental Protection Tax Law of the People's Republic of China to strengthen environment supervision and accountability and improve the public interest litigation system of environmental protection. These laws and regulations provide strong legal guarantee and support for the construction of ecological civilization system in counties. In the other hand, construction of ecological civilization system in counties has been effectively carried out. The corresponding organization of ecological civilization construction in counties has been continuously improved, and almost each county established a ecological county leadership group composed of County Magistrate County serving as the group leader, Secretary of the County Committee, First Deputy County Chief, NPC Deputy Director, Deputy County Chief in charge of environment, agriculture and urban construction, CPPCC Vice Chairman of the county serving as the deputy leader of the group as well as main leaders of member units of the County Development and Reform Bureau.

\section{Main Challenges FaCED By CONSTRUCTION OF ECOLOGICAL CIVILIZATION SYSTEM IN COUNTIES}

Firstly, there is a gap between the construction of ecological civilization system in counties and the requirements of ecological civilization construction of the country. The central government has established the construction of ecological civilization as a national strategy and considered it as an important task of building a moderately prosperous society in all aspects, but in comparatively, many county-level governments have not yet raise the ecological civilization to the height of regional strategy and of building a moderately prosperous society in all aspects and still equate the conventional ecological environment construction with ecological civilization construction. Although some counties have formulated the corresponding development plan, they still put economic development as the top priority during the implementation of the plan, and the construction of ecological civilization system has become formulaic. Construction of ecological civilization is comprehensive, strategic and comprehensive foundation for governing the country, but at the county level, the construction of ecological civilization, although having gradually come into the sight of policy making, is still at the edge.

Secondly, the organization management system has not matured. Construction of ecological civilization is a systematic project, which requires not only leaders who are able to make scientific decisions, but also executors who can implement the decisions, as well as well-developed evaluation and supervision mechanisms. The county level is the most direct output terminal of policy, which can clearly reveal the implementation degree of the policy. However, the current construction of ecological civilization of counties, the institutions formulated by the central and provincial governments are mostly included into the planning of the counties, that is, the counties successively release plans, work schemes, notices, etc relating construction of ecological county and ecological system, but they often ignore these polices in the practical working. Apart from the implementation that is unsatisfactory, there is also no evaluation and supervision mechanism for the ecological civilization system. In addition, the county governments have no specialized evaluation and supervisory organizations, and the existing institutions are either loose or weak. Therefore, their assessment on ecological civilization construction often fails to stress the key points, and the subject and method of evaluation and supervision are relatively simple, thus cannot exert the restrictive function effectively. Thus, the evaluation system remains to be developed, as it covers relatively more ecological and environmental indicators, and inadequate indicators of ecological culture, ecological system and ecological social construction. Besides, most of the indicators only assess the degree of the construction of ecological civilization system, and lacks the evaluation of the degree of effort and the progress of the construction. The existing cadre assessment indicators only cover the content of ecological environment construction and lack that of ecological civilization construction, so the index system is rigid enough but lacks flexibility. 
Thirdly, the degree of involvement of public is low. At present, most Chinese citizens have wake awareness of participation in democracy, and they just consider public affairs as problems that shall be solved by the government and position themselves as the passive receivers of the result of these public affairs. Civic participation will not go smoothly, and the scholar, an advocate of civic participation, also agrees that "it is not so easy to accept that civic participation is meaningful, it is hard to persuade and convince citizens to participate in management, and in any form of civic participation, it is especially difficult to endow a representative with more extensive representativeness." 2 . In one hand, there is a lack of feasible explicit provisions on civic participation in environmental protection and management and let alone benefit incentive. On the other hand, public participation is a type of participation that is advocated by and to cooperate with the government, lacking systematicness and continuity.

Fourthly, there is a lack of interregional cooperation and coordination. Construction of ecological environment system crossing administrative regions is often in vacuum, so there is a critical shortage of inter-region ecological compensation system. Construction of ecological environment system shall be considered strategically and from the whole, so in the early phase of system establishment, it shall take an overall consideration and respect the regional characteristics, and only in this way can the inter-region cooperation exert the maximum effect of the ecological system. However, in practice, the intrinsic requirement of construction of ecological civilization system often cannot be met.

Fifthly, shortage of fund for construction of ecological civilization system. As there is a large difference of economic development in different counties of China, so the financial situation varies from one county government to another. Thereinto, investment of county and township governments with poor financial situation in construction of ecological civilization is obviously inadequate, while that of county and township governments with excellent financial situation is often driven by preference. System construction is not a cloudcastle and it requires the support of corresponding financial and material resources.

\section{PATH TO PROMOTE THE CONSTRUCTION OF ECOLOGICAL CIVILIZATION IN COUNTIES}

\section{A. Developing the Ecological Responsibilities and Abilities of the Subjects of Responsibility for Construction of Ecological Civilization in Counties}

The ecological responsibilities of the responsible construction subjects are reflected through the process of "ecologicalization" of ideas and actions of multiple subjects including the government, enterprises, environmental NGOs, citizen individuals, etc, and mainly reflected in the ecological transformation of county-level governments' ideas; ecological nature of enterprises' actions; citizen individuals' ecological behaviors; ecological responsibilities of environmental NGOs, etc.

First is the dimension of the county government. " whether China can succeed in construction of ecological civilization, judging from the current and predictable situation, the government is playing the key role and is the core guarantee for China to move toward the ecological civilization"3. Therefore, as the core strength in the construction of ecological civilization system, the governments at all levels in counties are required to establish the scientific outlook on development and put people first so as to realize the harmonious relationship between man and nature. They shall also establish correct concept of political achievements. "the concept of political achievements is the general view of political achievements, and is a reflection of the outlook on development, including the understanding and attitude of the issues about the meaning of political achievement, creating political achievements for who, how to create political achievements, how to measure the political achievements, etc." " "Taking an overall viewpoint on political achievements means that we shall measure the political achievements from economic indicators, social indicators, humanity indicators as well as the environmental indicators; from both urban changes and rural development; from both current development and the sustainability of development; from both the growth of the gross economy and the benefits to the masses; from both the economic development and social stability; from both the "obvious achievements" and the "latent achievements"; from both the subjective efforts and the objective conditions" $"$.

Second is the dimension of public. It is necessary to establish fixed education propaganda positions, cultivate the public's knowledge of environmental protection and constantly improve the public's awareness of active participation in ecological construction. As for the difficulties encountered by citizen participation, Denhardt put forward that "Administrative officials have a duty to help educate citizens. And participation in civil rights activities has an education function that helps people not just think about their own interests but considers broader interests instead, and helps people understand the complexity of governance process." ${ }^{6}$ Education can be way to cultivate the public's interest and habit of citizen participation from their childhood and make politics a part of their life. People should be educated to know the government's institutions and laws, and learn how to use them actually. Giving full play to the role of news media in spreading ecological science knowledge and publicize the concept of protecting the ecological environment, enable people to accept ecological knowledge education in a subtle way, and learn how to express the ecological environmental appeal through legal channels and the measures and methods to safeguard their own ecological security.

Third is the dimension of enterprises. The economic activities of any enterprises have a responsibility to the ecological environment naturally. The construction of ecological civilization requires that enterprises shall treat nature fairly, the overexploitation of natural resources by enterprises be restricted, the maximum ecological balance of nature be maintained, and the spirit of all mankind's responsibility and a sense of responsibility for caring for nature and caring for nature be established truly, and the obligation to protect the ecological environment be fulfilled conscientiously. Enterprises have a decisive ecological responsibility for the market because of not only the formulation of ecological 
standard rules that can affect the market but also the ownership of larger power of rule making. And what is more important is that enterprises have the ability to generate "ecological competitive advantage" through the market. Meanwhile the government shall strengthen the internal and external motivation of enterprises to protect the ecological environment through incentive measures. More incentives can be used by the government to make the "protector income" form a supplement to "user payment".

\section{B. Establishing and Improving the Ecological Civilization System of Counties}

Firstly, to establish the property rights system of natural resources and strict environmental resource management system. The property rights system of natural resources shall be established. The government determines a sustainable scale according to the laws of nature, and then the nature resources have the rareness, so that the property rights can be given. Defining the right of disposition of natural resources assets and giving full play to the role of the market in the allocation of natural resources and assets, can make a deal of natural resource property rights on the market and allocate natural resources effectively. The government uses market, law, administration, technology and other means comprehensively to protect and restore the ecological environment and increase the space. The natural ecological spaces such as water, forests, mountains, grasslands, wasteland and tidal flat, shall be made a unified confirmation registration, so as to form a system of natural resource property rights with clear attribution, clear defined responsibility and effective supervision. The strict environmental resources management system are mainly improving the three respects of delimitation of property right of natural resources, determination of use of natural resources and supervision of natural resources.

Secondly, we will implement the resources paid use system and the system of ecological subsidies. The compensation areas shall be determined according to the characteristic of each county, including functional areas compensation, basin compensation and resource environment compensation. One is the regionalized management of different functional areas. The Ministry of Finance shall increase the vertical transfer payment for the key functional areas of ecological protection, so as to support ecological construction and environmental protection. At the same time, it is necessary to encourage public and other social forces to participate in ecological construction and provide ecological public products, and the initiative of all parties shall be mobilized fully. The other is the government playing a leading role. We can solve the interregional ecological compensation through inter governmental consultations and negotiations. Ecological benefit regions can also be compensated by ways of counterpart assistance and technical cooperation. The introduction of market mechanism is also an effective way to solve the problem of basin compensation.

Third is to implement a strict accountability system and maintain the durability of ecological civilization construction. At present, some leading cadres, for purpose of achieving "significant" achievements in their tenure, often pay more attention to the indicators of economic development and look down on the hidden indicators such as the construction of ecological civilization. Therefore, there will be a phenomenon of "making effort to the project with quick effect, and some projects with a long term affect need to make way for it". An important reason causing this result is that the existing accountability system is not perfect enough, which has led to many grassroots cadres pursuing only short-term effects while pushing the problem to the next official. This result shows the importance of "lifelong accountability system of responsibility". The implementation of responsibility system of ecological environment target, during the term of office of leading cadres, shall be included in the assessment contents. The "one ballot veto" of major environmental responsibility incident" shall be implemented. The leaders who ignore the ecological environment, blindly make decisions and cause serious consequences, must be held accountable and shall be prosecuted for life.

Fourth is to establish a system of ecological civilization evaluation and reward and punishment. The system of cadre evaluation shall be reformed, and resources consumption, environmental damage and ecological benefits shall be included in the evaluation system of economic and social development. It is necessary to establish target system, assessment method, reward and punishment mechanism which reflect the requirements of ecological civilization. Central Organization Department issued Notice on Improving Performance Appraisal of Local Party and Government Leading Groups and Leading Cadres in 2013 which stipulates clearly that the GDP and growth rate of the region shall not be ranked. Therefore, the assessment and evaluation of leading cadres shall be adjusted in time. The construction of ecological civilization shall be included in the standard of performance assessment, and the weight of indicators such as resource consumption and environmental protection shall be added. In terms of the practical situations of various counties including location conditions, industrial development, natural resources, economic foundation and living standards, different assessment rules shall be made to prevent simple nondiscretionary implementation.

Fifth is to improve the citizen's participation mechanism of ecological civilization construction. The perfection of citizen's participation mechanism needs the width and depth of public participation in public decision-making. At the same time, it is necessary to establish the guarantee mechanism of citizen's participation. Citizen's participation in decision-making can be improved from three aspects: first is the decision-making in the field of ecological construction, and the public shall be absorbed to participate in the demonstration stage. Second, for all involved in the ecological environment of resources, whether it is economic development or social improvement or improvement of people's livelihood, the public shall be absorbed to participate in the decision stage. And the new concept of ecological decision shall be established. Third, the assessment and evaluation of citizen's participation in ecological impact.

\section{CONCLUSION}

Construction of ecological civilization is a long-term systemic project and will not be accomplished at one stroke, 
and the construction of ecological civilization system is the strong support and powerful guarantee of the project. Therefore, it is the urgent requirement of the reality and theory to focus system construction in the construction of ecological civilization in counties of China. The goal of ecological civilization construction is to handle properly the relationship between man and nature and achieve the harmonious development of man and nature. The key to realize the harmonious development of man and nature lies in the human behavior, which is a reflection of the relationship between people. Therefore, the problem between man and nature is essentially a social problem, and solving social problems must depend on the system. System construction plays an important role in ecological civilization development of counties in China, so it is important to give full play of the guidance and constraint functions of the system to tell people what they are allowed to do and what they are not allowed to do; exert the incentive and urging functions of the system to make people have stable expectation that they can achieve stable profits as expected if they act according to the guidance of the system.

\section{REFERENCES}

[1] Xia Guang. Ecological Civilization and Institutional Innovation [J]. Theoretical Horizon, 2013 (1). 夏光 . 生态文明与制度创新 [J]. 理论视野, 2013( 1).

[2] [America] John Clayton Thomas. Public Participation in Public Decisions [M], China Renmin University Press, 2010: 27. [美]约翰・ 克莱顿・托马斯： 《公共决策中的公民参与》, 中国人民大学出版 社，2010 年版，第 27 页。

[3] Wang Hongbin. Ecological Civilization and Socialism [M], Central Compilation \& Translation Press, 2011: 174. 王宏斌. 生态文明与社会 主义 $[\mathrm{M}]$, 中央编译出版社，2011 年，第 174 页。

[4] Yang Jianjun. Implementation of Scientific Outlook on Development based on Correct Concept of Political Achievements [J], Study and Research, 2007(3). 杨建军. 坚持以正确政绩观落实科学发展观 [J]. 学 习与研究, 2007 ( 3).

[5] Sun Mingqi. Establish Correct Concept of Political Achievements: the Difficulties and Key to Implement Scientific Outlook on Development [J]. Practice \& Exploration, 2007( 2). 孙明奇. 树立正确政绩观: 落实 科学发展观的难点和关键 $[\mathrm{J}]$. 实践探索, 2007( 2)

[6] [America]Robert $・ \mathrm{~B} \cdot$ Denhardt, Janet $・ \mathrm{~V} \cdot$ Denhardt. New Public Service: Serving not Steering, China Renmin University Press, 2004:93. [美]罗伯特・B. 丹哈特、珍妮特 $\cdot V$. 丹哈特: 《新公务: 服务而不是 掌舵》, 中国人民大学出版社, 2004 年版, 第 93 页。 